William Whyte

\title{
THE PHANTASM OF AN UNIVERSITY: IMAGINING NEW LANDSCAPES IN POST-REVOLUTIONARY BRITAIN AND IRELAND
}

1789. The year of revolution. In July the Bastille would be stormed; in August the Declaration of the Rights of Man proclaimed. In November, the Constituent Assembly would expropriate Church property. Here was enlightenment indeed - and, of course, the revolutionary effects of these developments would soon be felt throughout Europe and the world. The Enlightenment and bloody revolution - enlightenment and the overthrow of the Ancien Régime - would become synonymous. However, beyond the French borders, normal life went on for a moment. Enlightenment continued to be safe: associated with progress and learning; with the development of the mind and the improvement of society. In Scotland, in particular, enlightenment and loyalty seemed to be two sides of the same coin. The late eighteenth century Scottish Enlightenment - especially in the universities - was an enlightenment of moderation, 'common sense', and the study, as the nineteenth-century journalist Walter Bagehot put it, of 'how, from being a savage, man rose to be a Scotchman'.

In November 1789 Edinburgh celebrated this Scottish Enlightenment with a grand new monument, laying the foundation stone for a great

DOI: https://doi.org/10.12697/BJAH.2018.15.04

1 Quoted in Hugh Trevor-Roper, 'The Scottish Enlightenment', History and the Enlightenment, ed. by John Robertson (New Haven, London: Yale University Press, 2010), 21. 
new university building. Designed by Robert Adam - an enlightened architect, whose circle included such enlightened thinkers as David Hume and Adam Smith - the new building, which is now known as the Old College, was an eloquent statement of enlightenment thought. By no means a visionary scheme, it was, as Andrew Fraser observes, a very specific plan for reconstructing - not radically reforming - the University. Dressed in a fashionable neoclassical style, surmounted with a dome, it was a civic as well as an academic building, contributing to the improvement of the city as a whole: it was an archetypally progressive project. ${ }^{2}$ Appropriately enough, the foundation stone would be laid by the Grand Master of the Scottish Masons, Lord Napier, who exclaimed: 'May the Grand Architect of the Universe grant a blessing on this foundation stone, and by his Providence enable us to finish this and every other work which may be undertaken for the embellishment and advantage of this city. ${ }^{3}$ His combination of freemasonry and deism, high-thinking and civic improvement perfectly matched the building he was celebrating: a building both designed to be - and to be part of - a genuine enlightenment landscape.

The French Revolution - and the wars it precipitated - brought this ambitious plan to a halt. Despite the boosterism, in spite of all the enlightened enthusiasm, even with a lottery established to raise funds, work on the new buildings for Edinburgh University would grind to a halt and remain uncompleted until it was begun again in 1815 . But nonetheless the ambitions and ideals expressed in Edinburgh in November 1789 bear further examination. In the first place, they speak of the multiple ways in which the Enlightenment was experienced in Britain; for, as Roy Porter once observed, there was never 'un petit troupeau des philosophes' within the Atlantic archipelago. Rather, the enlightened figures of England, Scotland, and Ireland can, in his words, be 'better likened to the mixed clientele talking, talking, talking in a hot, smoky and crowded coffee house; men sharing broad convictions and sympathies, but differing, and agreeing to differ, on matters dear to their hearts. ${ }^{4}$ Secondly, this example illustrates the way in which the state became involved in higher education in the late eighteenth and early

2 Andrew G. Fraser, The Building of Old College: Adam, Playfair, and the University of Edinburgh (Edinburgh: Edinburgh University Press, 1989), 27.

3 Quoted in ibidem, 5.

4 Roy Porter, Enlightenment: Britain and the Creation of the Modern World (London: Penguin, 2000), xviii. 
nineteenth centuries. Often seen as a moment in which government interest was directed elsewhere, ${ }^{5}$ this was in fact a time when the British state invested heavily in higher education. ${ }^{6}$ It is worth noting that Edinburgh would only see its new home built as a result of the $£ 80,000$ it was granted by a vote of the House of Commons. Above all, the excitement of November 1789, the disappointments which ensued, and the ultimate realization of something approaching William Adams' dream in the years that followed the peace should serve to remind us that this period of university history, which is often passed over by historians as an era of stasis, was actually one of change, dynamism, and real interest: even in Britain, which escaped the 'unprecedented and traumatic upheaval' visited on the institutes of higher learning in continental Europe. ${ }^{7}$

Edinburgh's example is also useful because it illustrates how these social, political, and intellectual developments were expressed in architectural form. The neoclassicism adopted by William Adam and his successors at the university was the product of taste and fashion. It also reflected a contextual response to the prevailing style of Scotland's capital, which had, since the 1760s, embraced a granite-faced classical style. But it was more than. The neoclassicism of Edinburgh's university echoed the pompously-pedimented Examination Hall and Chapel at Trinity College Dublin, built from 1777 onwards. This was, as the architectural historian John New man has put it, a 'national style': an architecture unified by its imposing form and its solid, rusticated, pedimented facades. ${ }^{8}$ Of course, it was also an explicitly academic approach: learned in its reference to past architecture; and scholarly, as well, not least in its use of symbols like pediments, domes, and triumphal arches, which were deployed to symbolize the university in institutions all across the

5 Sheldon Rothblatt, Martin Tow, 'Government Policies and Higher Education: A Comparison of Britain and the United States, 1630-1860', Social Research and Social Reform: Essays in Honour of A. H. Halsey, ed. by Colin Crouch, Anthony Heath (Oxford: Oxford University Press, 1992), 173-216.

6 William Whyte, Redbrick: A Social and Architectural History of Britain's Civic Universities (Oxford: Oxford University Press, 2015), 27.

7 Laurence W. B. Brockliss, 'The European University in the Age of Revolution, 1789-1850', The History of the University of Oxford, vol. VI. Nineteenth-Century Oxford, part 1, ed. by Michael G. Brock, Mark C. Curthoys (Oxford: Oxford University Press, 1997), 84.

8 John Newman, 'Somerset House and other Public Buildings', Sir William Chambers: Architect to George III, ed. by John Harris, Michael Snodin (New Haven, London: Yale University Press, 1996), 114. 
world. Just like Johann Wilhelm Krause's Tartu, this was a building intended to speak 'the language of rules of eternal beauty, harmony and perfection. ${ }^{9}$

This rising tide of enlightened architecture even affected the two ancient English universities - Oxford and Cambridge - which are so often seen as being sunk in an unthinking, reactionary conservatism during this period: 'a sluggish stream meandering between overgrown meadows, contrasting sharply with the torrents of intellectual activity that came before and would follow after. ${ }^{10}$ At Cambridge, in particular, the building of Downing (1807-1822) represented a remarkable - and remarkably complete - attempt to construct a classical college. The first new foundation for centuries, and the first major project designed by the scholarly William Wilkins, Downing was a landmark of what the architectural historian David Watkin has termed 'The triumph of the Classical' in Cambridge architecture. ${ }^{11}$ Although - like Adams' Edinburgh - budgetary constraints would leave it unfinished, the plan was a testament to two principles. Firstly, with Doric and Ionic orders, its quotations from the Athenian Propylaea and the Erechtheum, it was a virtuosic display of its architect's learning. Secondly, and still more critically, the unity of its conception and the form it took made Downing, in the words of Simon Bradley, 'the earliest university college on the campus plan' ever built, predating Jefferson's Virginia by a decade. ${ }^{12}$

Oxford had nothing quite so adventurous to show. Its neoclassical reconstruction of Hertford College was small in scale and pathetically incomplete in comparison. But its Radcliffe Observatory, built by James Wyatt from 1776, does show the university trying to keep up. Both its function and its form - for it was modelled after the Athenian Tower of the Winds - were highly fashionable. In the words of Wyatt's biographer, when built it was both 'the finest observatory in Europe' and 'one of the supreme architectural monuments of the

9 Juhan Maiste, Kadi Polli, Mariann Raisma, Alma Mater Tartuensis: Tartu Ülikool ja tema arhitekt Johann Wilhelm Krause (Tartu: Eesti Keele Sihtasutus, 2003), 293.

10 Leslie G. Mitchell, 'Introduction', The History of the University of Oxford, vol. V. The Eighteenth Century, ed. by Leslie G. Mitchell, Lucy S. Sutherland (Oxford: Clarendon Press, 1986), 1. The rest of the volume helps demonstrate that this cliché is unsustainable.

11 David Watkin, The Triumph of the Classical: Cambridge Architecture, 1804-1834 (Cambridge: Fitzwilliam Museum, 1977).

12 Simon Bradley, Nikolaus Pevsner, The Buildings of England: Cambridgeshire (New Haven, London: Yale University Press, 2014), 84. 
English Enlightenment, combining advanced ideas and superbly made scientific equipment with innovative neoclassical architecture. ${ }^{13}$ The subsequent construction of structures such as the triumphal-arched Clarendon Press Building (1826-1827), designed by the Adams-trained Daniel Robertson, or the new neoclassical homes for the university art gallery (or Ashmolean) and school of languages (or Taylorian), designed by the scholarly Charles Robert Cockerell and built between 1841 and 1845, show how long this tradition continued.

These developments - buildings and projects which can be found in Scotland, Ireland, and in both the English universities are noteworthy in their own right. They also provide an important context for another development: the foundation of a university in London; a development often misunderstood precisely because it is studied in isolation. Established in 1826, the University of London or University College London, as it would become known - was an entirely new and self-consciously modern institution. Its inspiration was, at least in part, derived from the reformed university of Berlin and its founders were determined to create a non-denominational foundation, a place offering useful learning as well as the liberal arts. Yet if these features distinguished it from the traditional idea of the university in England, other elements more closely cleaved to the way in which higher education had developed in the recent past. Significantly, the architect of the new college was William Wilkins, working in the mode that he pioneered at Downing. It was, the architect averred, a campus designed to achieve 'magnificence', and, with its dome and Doric gateway - designed to evoke the entrance to the Acropolis. Moreover, its ten-columned portico modelled after the Athenian Temple of Jupiter Olympus was certainly intended to be imposing. ${ }^{14}$ It was also an enlightened landscape: set down in a newly-developed part of London and celebrated as 'a palace for genius ... where future Ciceros should record their influence of that incitement which Tully declares he felt at Athens, when he contemplated the porticoes where Socrates sat'.15 And, like the other university buildings we have noted, it was also a place where idealism

13 John Martin Robinson, James Wyatt, 1746-1813: Architect to George III (New Haven, London: Yale University Press, 2012), 200.

14 Whyte, Redbrick, 55.

15 Ibidem, 53. 
exceeded the material resources of its backers. It would take more than a century for Wilkins' metropolitan university to be completed, and, in the meantime, its monumental entranceway would notoriously remain 'the grandest entrance in London with nothing behind it'. ${ }^{16}$

University College London (UCL) is thus very much part of a broader architectural trend. In its design, in its ambition, and in its consequent failure to be completed, it resembles more than it differs from Downing, Hertford, Edinburgh, and numerous other projects elsewhere. The fact that the people planning these schemes left behind little evidence of the ideas which underlay their proposals makes it difficult to say anything more about them. Historians are reliant on scraps of information: for example, on the few letters exchanged by Wilkins and his disgruntled paymasters at UCL; ${ }^{17}$ or on the brief and sometimes cryptic descriptions of buildings, including Cockerell's Ashmolean and Taylorian, in the periodical press. ${ }^{18}$ In that respect, the less than forty words uttered by the Grand Master of the Scottish freemasons in 1789 provide an uniquely revealing glimpse of the enlightened sensibilities and intentions of those who built these places.

All of which makes Charles Kelsall's magnum opus of 1814 - the Phantasm of an University - a uniquely revealing and remarkably resonant source. ${ }^{19}$ True enough, the plans it presented were never enacted. Despite the author's attempts to influence Jefferson's Virginia and Wilkins' London, his designs seem have had no real effect on either. Even the suggestion that his ideas helped shape the layout of Cornell is only tentative and speculative. ${ }^{20}$ But, as we have seen, a failure to complete projects was not unusual in a period that witnessed an unhappy combination of economic uncertainty and vaunting academic ambition. Moreover, and more importantly still, Kelsall's programme - for all its unrealized and perhaps unrealizable grandeur - brilliantly encapsulates many of the themes which run throughout

16 Negley Harte, John North, The World of UCL, 1828-1990 (London: Routledge, 1991), 45.

17 Whyte, Redbrick, 54-55.

18 Anne Bordeleau, Charles Robert Cockerell, Architect in Time: Reflections around Anachronistic Drawings (Farnham: Ashgate, 2014), 142-144, provides a very nice example of how creatively these can be interpreted.

19 I also discuss some of these themes in Redbrick, 1-6.

20 Kermit C. Parsons, 'The Quad on the Hill: An Account of the First Buildings at Cornell', Journal of the Society of Architectural Historians, 22 (1963), 199-216. 
university life in post-revolutionary Britain. Consequently, it repays attention as a distillation - or even a culmination - of the debates that reshaped British university life and university landscapes in the light of the Enlightenment.

Charles Kelsall was himself a deeply enlightened individual: a man, in the words of the reactionary architectural historian David Watkin, who 'could not observe any facet of human existence without wishing to liberalize and modernize it. ${ }^{21} \mathrm{He}$ was a Hellenist, an antiPapist, an advocate for political, social, and aesthetic reform. He even urged that Windsor Castle be rebuilt in a modern, progressive, neoclassical style. ${ }^{22}$ The Phantasm of an University drew on all these interests and also on his own experience of Cambridge, which as a former student, he found lacking in very many respects. Kelsall envisaged a university that would transcend the limitations of existing institutions. One that would focus on the real needs of individuals, whilst also offering a good general education. It would not seek narrow specialism in textual analysis or abstract mathematics but would encourage the serious study of the political sciences, moral philosophy, commercial studies, agriculture, manufacturing, and a host of other subjects neglected by older institutions. By uniting all disciplines, it would make each one more brilliant. By rationalizing study, it would reduce insanity and raise the standards of literature whilst also combating any sense of rivalry between the different branches of knowledge. Above all, it would teach each person what they needed to know - both for themselves and for the wider good of humanity. In other words, the Phantasm was a panacea; a utopian, enlightened dream of a university that would 'be to [the] nation, what the sun is to our system, the grand centre, from which the rays of universal knowledge should emanate, and by which the career of all the luminaries of science should be regulated and directed.' ${ }^{23}$

Here was an enlightenment ideal indeed. Initially, Kelsall envisaged the complete conversion of all the Oxford and Cambridge colleges into new foundations, with Oxford's Christ Church becoming a centre of 'Civil Polity and Languages'; Magdalen, Queen's, and University

21 David Watkin, 'Charles Kelsall: The Quintessence of Neo-Classicism', Architectural Review, 140 (1966), 11.

22 Charles Kelsall, A Letter to the Society of the Dilettanti on the Works in Progress at Windsor Castle by Mela Britannicus (London: J. Davy, 1827).

23 Charles Kelsall, Phantasm of an University (London: White, Cochrane and Co., 1814), 38-39. 
recreated as colleges of 'Moral Philosophy'; New College and Trinity devoted to 'Fine Arts'; Brasenose, Balliol, and Oriel dedicated to 'Natural Philosophy'; and the others evolving into institutes of 'Agriculture and Manufactures' or 'Mathematics'. ${ }^{24}$ However, even Kelsall recognised that such radical rationalization was unlikely; so he devoted a substantial section of his volume to his grand plan for a 'sublime' university set down in the countryside of central England; a 'healthy and cheerful spot' in Staffordshire where the 'silver Trent' would 'mæander at the end of the University Grove. ${ }^{25}$ Even this location was symbolically significant, for Staffordshire was in the heartland of the late eighteenth century English Enlightenment. It was the home of the natural philosopher Erasmus Darwin; the scene of many of Thomas Telford's greatest engineering works; the location of Josiah Wedgwood's pioneering model factories. Neighbouring Shropshire and nearby Birmingham were still more central to enlightened thought. ${ }^{26}$ This was, then, intended to be an enlightened institution set within an enlightenment world.

Kelsall's masterplan for this putative new university was every bit as progressive as the foundation it was designed to house. The whole place was to be comprised of seven colleges in seven courtyards somewhat larger than Lincoln Inn Fields. The scale of the enterprise can be gauged by the fact that, Lincoln's Inn Fields, which was nearly five hectares in size, was London's largest square. It was also - in a nice enlightened touch - popularly supposed to have been modelled after the dimensions of the great pyramid at Giza. ${ }^{27}$ Kelsall's plans did not merely encompass grand buildings. The landscape was to be reshaped by this utopian institution. It would include a botanical garden with an observatory and anatomy theatre; a zoo, complete with 'Boas' and 'Oran-outangs'; and a grove of trees - 'chiefly ... planes,

24 At Cambridge, Trinity would teach civil polity and languages; St John's, Magdalen and Sidney Sussex moral philosophy; Downing Christ's, and Emmanuel fine arts; Clare and Queens' natural philosophy; Pembroke and Peterhouse agriculture and mathematics; 'Leaving the rest Colleges of Mathematics, which, with the exception of King's, they nearly are'. Kelsall, Phantasm of an University, 118-119.

25 Ibidem, 129, 170.

26 See, for instance, Roger Neil Bruton, The Shropshire Enlightenment: A Regional Study of Intellectual Activity in the Late Eighteenth and Early Nineteenth Centuries. PhD dissertation (Birmingham: University of Birmingham, 2015); Peter M. Jones, Industrial Enlightenment: Science, Technology and Culture in Birmingham and the West Midlands, 1760-1820 (Manchester: Manchester University Press, 2009). 
cedars of Lebanon, cypresses, beeches, oaks, and Spanish chestnuts' - more than a mile in length. Criss-crossed with formal walks, and axial views terminating with the university press - 'consisting of a square range of seven hundred and seventy-six columns' - the surroundings would be enclosed by railings inspired by the Summer Palace at St Petersburg and fountains derived from Maderno and Bernini's work at St Peter's in Rome. ${ }^{28}$

The buildings, however, cannot be ignored. For they were intended to do more than simply impress - although, it must be acknowledged that the chapel, which Kelsall described as an improved version of Rheims Cathedral, was certainly intended to overawe. Rather, just like the grounds, all the buildings were meant more generally to elevate and educate their inhabitants. The reliefs in the porticos illustrated the foundation of the Library of Alexandria, Nicias' protest against the Syracusan expedition, the death of Archimedes, Leibniz writing to Newton about his discovery of fluxion, and much, much more besides. The statues included such unlikely combinations as Tiberius, Nero, Caligula, and Domitian 'attired as the lowest slaves' and supporting the emperor Trajan: 'that brightest ornament of a monarchical state'. Most striking of all was Kelsall's decision to adopt a variety of styles for each college. For whilst he praised the revival of Greek architecture and singled out 'Hertford and Downing Colleges' as being amongst the half-dozen best examples of the genre, he evidently wished to expose his imaginary students to an array of different aesthetics. Thus, there were Saxon and Norman, Gothic and Tudor facades as well as what he described as 'ItaloGrecian Elevations'. ${ }^{29}$

Given the scale and the speculative nature of these ambitions, it should come as no surprise to learn that nothing came of Kelsall's vision. The sheer cost of the enterprise, which he conservatively estimated at $£ 5$ million - or more than the entire British state spent on everything apart from defence - made his dream impossible. The Phantasm is, however, an important and revealing source, not least because of what it tells us about the wider world of university landscapes in this period.

28 Kelsall, Phantasm of an University, 159, 171, 161.

29 Ibidem, 138, 127, 175. 
In the first place, as I have argued elsewhere, the Phantasm of an University speaks of a remarkable moment in the history of British higher education. ${ }^{30}$ Far from being a time of inertia or much less decline, the late eighteenth and early nineteenth centuries would witness a staggering slew of schemes for new universities. There were debates about new foundations in Ireland and England and throughout the British Empire. There were even plans to bring the Genevan Academy to the small and sleepy ancient Irish town of Waterford..$^{31}$ The existing universities were also experiencing change - and growth. Whilst the French Revolution and the wars which followed would cut a swathe through the institutes of higher education on the continent - leaving, in the words of one expert, the European university looking like 'a doomed species' Oxford, Cambridge, Edinburgh, Trinity Dublin, and the others all experienced quite remarkable expansion. ${ }^{32}$ Student numbers were up and ambitions were rising too. New social groups and those excluded by their faith from the confessional universities of England were hatching plans for their own institutions: plans that would find a sort of fulfilment in the foundation of UCL. That Kelsall's vision was never built - and could never be built - is also suggestive, because it speaks of the way in which numerous proposals of the period, not least for UCL or the Edinburgh University building with which we began, turned out to be too ambitious, as the idealism of their backers proved too expansive and expensive in stringent times. In that sense, the Phantasm was not so much a fantasy as a sort of apotheosis: a summation of all the ambition and imagination that was being directed towards university life.

The Phantasm of an University likewise illustrates another important point: the crucial role of architecture and landscape design in helping to reimagine and reform the university. For Kelsall, and many other Enlightenment figures, the students' surroundings were not just a backdrop. Buildings were intended to symbolize the institution they housed; gardens and parks were meant to provide opportunities for education, reflection, and contemplation. Of course, this was

30 Whyte, Redbrick, 29-33.

31 Jennifer Powell McNutt, Richard Whatmore, 'The Attempts to Transfer the Geneva Academy to Ireland and to America, 1782-1795', Historical Journal, 56 (2013), 345-368.

32 Brockliss, 'The European University in the Age of Revolution', 100. 
a product of the cult of the picturesque and the obsession with landscapes that animated such a broad public in the period. Although Kelsall's grand dream would remain just a dream, and although urban universities like Edinburgh or UCL had little room to play with, it is noteworthy that in Cambridge, for instance, there was a renewed interest in the parkland - or Backs - bordering the river Cam. Indeed, plans would be drawn up for the Backs by Launcelot 'Capability' Brown, the preeminent garden designer of the day. ${ }^{33}$ Predictably enough, these were never completed; but they nonetheless confirm this new sensibility.

Thirdly, Kelsall's concept of a university the art and architecture of which would exhibit the best styles of the past, whether classical or Gothic, Greek or even Saxon, is an important reminder of the aesthetic pluralism that became increasingly widespread as the eighteenth century gave way to the nineteenth. This was a plastic period in which stylistic adaptability became acceptable. Neoclassicism - especially Greek neoclassicism - retained its purchase, to be sure; but other styles came to be seen as suitable on contextual or associational grounds. Thus, for instance, the architect of Oxford's neo-Roman University Press would also build Gothic Revival additions to nearby colleges. ${ }^{34}$ So too, as Howard Colvin has shown, the years between 1790 and 1820 at Magdalen College, Oxford, would witness a bewildering range of proposals - all picturesque, to be sure - and each exhibiting influences from ancient Greece to seventeenth-century England. ${ }^{35}$ This stylistic experimentation was all of piece with the intellectual excitement that characterized contemporary debates about university life.

This period of aesthetic, intellectual, and institutional adaptability did not last long and was soon forgotten. By the middle of the nineteenth century, the appropriate architectural style for British and Irish universities had unquestionably become Gothic. In Oxford, as one historian has remarked, 'the cry was for Gothic, the whole

33 Marcus Whiffen, 'Academical Elysium - The Landscaping of the Cambridge Backs', Architectural Review, 101 (601) (1947), 13-18.

34 William Whyte, 'Robertson, Daniel (c.1770-1849)', Oxford Dictionary of National Biograph (Oxford: Oxford University Press, 2016). See: http://www.oxforddnb.com/view/article/109384 [accessed 28 April 2017].

35 Howard Colvin, Unbuilt Oxford (New Haven, London: Yale University Press, 1983), 85-99. 
Gothic, and nothing but the Gothic.. ${ }^{36}$ In the newly-founded colleges of Galway and Cork, Belfast and Birmingham, Manchester, Liverpool, and Leeds, neo-medievalism carried all before it. ${ }^{37}$ This homogeneity of architectural form reflected a growing consensus on academic life: a consensus which would create the modern British university system as it still exists today. The Phantasm of the University is important not least because it stands as a testament to an earlier, more fluid, more experimental moment: a time when enlightened thinkers conjured up dreams of new enlightened landscapes of learning. The fact that times change explains why this moment was forgotten and also why it deserves to be remembered.

William Whyte: The Phantasm of an University: Imagining New Landscapes in Post-Revolutionary Britain and Ireland

Keywords: Enlightenment; University of Edinburgh; Trinity College Dublin; University of Oxford; University of Cambridge; Charles Kelsall

William Whyte is Professor of Social and Architectural History at the University of Oxford. His research has focused on the built and natural environment in the context of modern British and European history. His PhD thesis (2002, University of Oxford) was published as Oxford Jackson: Architecture, Education, Status and Style, 1835-1924 (2006). His most recent publications include Redbrick: A Social and Architectural History of Britain's Civic Universities (2015) and Unlocking the Church: the Lost Secrets of Victorian Sacred Space (2017). Together with prof. Dan Hicks, he is series editor of the six-volume Bloomsbury Cultural History of Objects. William Whyte is also the chairman of the Oxford Historical Society, chairman of the Oxford Preservation Trust, a member of the editorial board of the Oxford Review of Education, and a member of the International Commission for the History of Universities.

36 Edmund A. Greening Lamborn, quoted in William Whyte, 'Unbuilt Hertford: T. G. Jackson's Contextual Dilemmas', Architectural History, 45 (2002), 351.

37 Whyte, Redbrick, 101-118. 